AUTHOR CORRECTION

\title{
Author Correction: Increased rainfall stimulates permafrost thaw across a variety of Interior Alaskan boreal ecosystems
}

Thomas A. Douglas (D), Merritt R. Turetsky and Charles D. Koven (iD)

npj Climate and Atmospheric Science (2020)3:50; https://doi.org/10.1038/s41612-020-00155-6

Correction to: npj Climate and Atmospheric Science https://doi.org/ 10.1038/s41612-020-0130-4, published online 25 July 2020

The original version of the Supplementary Information associated with this Article contained an error in Supplementary Table 1 in which incorrect values were given in the fourth and fifth columns. The correct version of Supplementary Table 1 is:

\begin{tabular}{llllll}
\hline Year & $\begin{array}{l}\text { Total summer } \\
\text { precipitation } \\
(\mathrm{cm})^{1}\end{array}$ & $\begin{array}{l}\text { Summer } \\
\text { precipitation } \\
\text { ranking (out of } \\
91 \text { years) }\end{array}$ & $\begin{array}{l}\text { Mean summer } \\
\text { air } \\
\text { temperature } \\
\left({ }^{\circ} \mathrm{C}\right)^{1}\end{array}$ & $\begin{array}{l}\text { Cumulative } \\
\text { heating } \\
\text { degree days }{ }^{1}\end{array}$ & $\begin{array}{l}\text { End of winter } \\
\text { snowpack (cm) }\end{array}$ \\
\hline 2013 & 14.5 & 69 & 12.5 & 2042.2 & 181.4 \\
2014 & 37.1 & 1 & 12.1 & 1964.4 & 102.3 \\
2015 & 20.8 & 24 & 12.0 & 1963.1 & 162.3 \\
2016 & 33.0 & 3 & 13.1 & 2137.8 & 98.8 \\
2017 & 19.9 & 27 & 13.4 & 2180.0 & 209.7 \\
$\begin{array}{l}\text { Mean } \\
(1929-2018)\end{array}$ & 18.5 & & 11.6 & 2221.8 & 156.1 \\
\hline
\end{tabular}

${ }^{1}$ The summer season for this study is defined as the time between May 1 and October 10.

which replaces the previous incorrect version:

\begin{tabular}{llllll}
\hline Year & $\begin{array}{l}\text { Total } \\
\text { summer } \\
\text { precipitation } \\
(\mathrm{cm})^{1}\end{array}$ & $\begin{array}{l}\text { Summer } \\
\text { precipitation } \\
\text { ranking (out of } \\
91 \text { years) }\end{array}$ & $\begin{array}{l}\text { Mean } \\
\text { summer air } \\
\text { temperature } \\
\left({ }^{\circ} \mathrm{C}\right)^{1}\end{array}$ & $\begin{array}{l}\text { Cumulative } \\
\text { heating } \\
\text { degree days }\end{array}$ & $\begin{array}{l}\text { End of winter } \\
\text { snowpack (cm) }\end{array}$ \\
\hline 2013 & 14.5 & 69 & 12.2 & 1133.3 & 181.4 \\
2014 & 37.1 & 1 & 12.5 & 945.6 & 102.3 \\
2015 & 20.8 & 24 & 12.8 & 876.7 & 162.3 \\
\hline
\end{tabular}

Table continued

\begin{tabular}{lllllc}
\hline Year & $\begin{array}{l}\text { Total } \\
\text { summer } \\
\text { precipitation } \\
(\mathrm{cm})^{1}\end{array}$ & $\begin{array}{l}\text { Summer } \\
\text { precipitation } \\
\text { ranking (out of } \\
\text { 91 years) }\end{array}$ & $\begin{array}{l}\text { Mean } \\
\text { summer air } \\
\text { temperature } \\
\left({ }^{\circ} \mathrm{C}\right)^{1}\end{array}$ & $\begin{array}{l}\text { Cumulative } \\
\text { heating } \\
\text { degree days }\end{array}$ & $\begin{array}{l}\text { End of winter } \\
\text { snowpack (cm) }\end{array}$ \\
\hline 2016 & 33.0 & 3 & 11.8 & 1253.9 & 98.8 \\
2017 & 19.9 & 27 & 13.9 & 714.4 & 209.7 \\
$\begin{array}{l}\text { Mean } \\
(1929-2018)\end{array}$ & 18.5 & & 11.8 & 1085.0 & 156.1 \\
\hline
\end{tabular}

${ }^{1}$ The summer season for this study is defined as the time between May 1 and October 10.

The HTML has been updated to include a corrected version of the Supplementary Information. Attribution 4.0 International License, which permits use, sharing, adaptation, distribution and reproduction in any medium or format, as long as you give appropriate credit to the original author(s) and the source, provide a link to the Creative Commons license, and indicate if changes were made. The images or other third party material in this article are included in the article's Creative Commons license, unless indicated otherwise in a credit line to the material. If material is not included in the article's Creative Commons license and your intended use is not permitted by statutory regulation or exceeds the permitted use, you will need to obtain permission directly from the copyright holder. To view a copy of this license, visit http://creativecommons. org/licenses/by/4.0/.

This is a U.S. government work and not under copyright protection in the U.S.; foreign copyright protection may apply 2020 